This item was submitted to Loughborough's Research Repository by the author.

Items in Figshare are protected by copyright, with all rights reserved, unless otherwise indicated.

\title{
Realism, values and critique
}

PLEASE CITE THE PUBLISHED VERSION

https://doi.org/10.1080/14767430.2019.1614744

PUBLISHER

(c) Taylor \& Francis

VERSION

AM (Accepted Manuscript)

PUBLISHER STATEMENT

This is an Accepted Manuscript of an article published by Taylor \& Francis in Journal of Critical Realism on 30 May 2019, available online: https://doi.org/10.1080/14767430.2019.1614744

\section{LICENCE}

CC BY-NC-ND 4.0

\section{REPOSITORY RECORD}

Elder-Vass, Dave. 2019. "Realism, Values and Critique". figshare. https://hdl.handle.net/2134/37838. 


\title{
Realism, values and critique ${ }^{1}$
}

\author{
Dave Elder-Vass
}

d.elder-vass@lboro.ac.uk

Loughborough University

*** This is a pre-publication version of a paper to be published in the Journal of Critical Realism. The version of record can be found at https://doi.org/10.1080/14767430.2019.1614744 ***

Abstract: This is a lightly edited transcript of a plenary talk given at the Beyond Positivism conference, Montreal, August 8-10 2017. The talk followed others by Christopher Winship and Frédéric Vandenberghe, which are mentioned in the text. The paper argues that critical social science needs an ontology of values, and that a coherent ontology must recognise that values are created by human beings in social settings, rather than being objectively true. Recognising this, however, need not expose us to the moral nihilism of extreme relativism. Drawing on the work of Habermas and the capabilities approach, I argue that we can reason about what sorts of basic values we should be committed to, without invoking the concept of objective values. The provides us with material that we can build on to construct more complex constructive critical arguments

Keywords: capabilities approach, discourse ethics, ethical naturalism, moral realism, relativism.

One of the many ways in which critical realism goes beyond positivism is in rejecting the idea that social science can or should be ethically neutral. Most critical realists see it as part of the role of social scientists to criticise unjust social arrangements. Indeed many of us are social scientists because we believe that social science has something to contribute to social or political critique.

\footnotetext{
${ }^{1}$ My thanks to Ito Jimenez for recording the talk.
} 
But for philosophically oriented social scientists, as critical realists are, critique cannot come from nowhere. It must have some deeper basis, some sort of ethical justification, and for critical realists that inevitably raises the question that Chris Winship asked a few minutes ago: the question of the ontology of values, the ontology of the ethics on which we base our critique. Chris asked where critical realism stands on this question of the ontological basis of morality. I think the truth is that critical realists have taken a variety of different stances on the ontological status of morality and today I want to say something about that debate. In particular there are two conflicting positions that I want to discuss. First I'll talk briefly about moral realism, the position taken by Roy Bhaskar, but then I will oppose to that what I think is a more scientifically realist and a more social realist understanding of the ontology of values, In this view values are social products, and that means abandoning some of the beliefs that moral realism entails about the objectivity of values. This might seem to open the way for the spectre of relativism that some people have worried about at this conference but I will argue that despite moving away from a strong moral realism we can be judgementally rational about values. I'm going to outline one way in which we might do that which invokes, like both Chris and Fred, the work of Jürgen Habermas and in particular the concept of discourse ethics. Before starting I should also mention that most of what I am going to say today has been said more coherently, more rigorously and more fully in an earlier paper (Elder-Vass, 2010a).

It should already be clear from my introduction that realists can disagree on just what is and what is not real. For Bhaskar one of the things that was real was an objective morality. This is the idea that values are objectively real, not just in the sense that they exist in our heads, but also that they exist independently of people's beliefs about value, they exist independently of social structures around value, and thus independently of any person or society. Now, in his work he made a number of attempts to justify this position. The first one, the idea of cognitively based explanatory critique, which argues that the sources of false knowledge should be removed, comes from his early book Scientific Realism and Human Emancipation (Bhaskar, 1986). The second one, which we may call needs-based explanatory critique because it extends this argument to the claim that the sources of failures to meet human needs should be removed, is developed in the Dialectic (Bhaskar, 1993). The third, referring to the concept of our ground state, a sort of loving identification with the universe, appears in the metareal stage of his thinking (e.g. Bhaskar, 2002). In the paper I mentioned earlier (Elder-Vass, 2010a) I criticise all three of those arguments, but I'm not going to go into that in any depth today because I want to focus more on the constructive aspect of my argument. Let me just say that nothing that Bhaskar says in any of these defences of moral realism or ethical naturalism seems to me to solve the issue of the ontological status of these so-called objective values. When someone says to me there are objective values the question I ask is how could such a thing exist? Values can exist in peoples' heads 
and there are many different ways in which we can communicate values through material objects, but how else could they exist? To say that a value is in our head is not to say that it is objectively true or objectively right, but this is what Bhaskar wants out of moral realism, that values don't just exist but that they are objectively right or objectively true. Again I discuss this in more depth in the paper but it seems to me very difficult to see how one could provide a plausible ontology of values that are objective in this sense.

If there is no such thing as an objective morality then it seems to some that the spectre of relativism rears its head. Someone said yesterday that one reason that many positivists are positivists is that they are frightened or at least concerned about the spectre of relativism. I think that's true of many realists too, and perhaps it produces a temptation to accept moral realism, but I want to suggest that we can resist the more nihilistic varieties of relativism without moral realism. We can have a more plausible ontology of values which recognises that they are not objectively right while still providing us with the opportunity to build well-founded constructive moral arguments. So I'd like to say a little bit about what would be involved in what I think is a more coherent realist ontology of values.

First of all, rather than existing somewhere beyond the human realm, and this is a fairly straightforward sociological argument that I think should appeal to social scientists, values are human products. They exist most concretely in our heads as beliefs or dispositions about what is right or good. In that sense they are emergent mental properties of human beings, but we develop these beliefs and dispositions on the basis of social interactions, and those beliefs that come to be regarded as values are on the whole those beliefs that we find other people espousing in their interactions with us. One way of thinking about this social influence is that there are groups of people (that I have theorised as norm circles, e.g. in Elder-Vass, 2010b), that influence the way that we think about what is normatively right. In saying that I am resisting a strong distinction between norms and values - for me values are just one variety of socially produced normative construct.

Now, to say that our values are a product of social influences is not to say that social influences completely determine our values because we also have a reflexive capacity to think for ourselves about values. Our personal values can diverge from the values that our social context seems to suggest although that is perhaps relatively rare. However, it is also possible for different and competing values to be espoused by different social groups and this creates the possibility that there can be multiple different values in competition in the same social context. In this ontology, values exist in a real form, but they are potentially different for different people in different societies and even for different people in the same society. So this kind of realism about values is not a form of moral realism, because moral realism implies, not just that values take a certain form, but also that they are correct, 
they are right, they are true. Whereas in the kind of ontology of values I am advocating here those two questions become separated. One consequence is that this ontology of values leaves us still needing to address a subsequent question: how can we justify any particular value?

How might we develop such a justification with this kind of view of what values are? Well, first of all I think it's clear and uncontroversial to say that when people develop social critiques they base them on values, and I think critique is also a matter of judging some social arrangement to be inadequate on the basis of some ethical standard. I also suggest that we can reason about what sorts of basic values we should be committed to, without invoking the concept of objective values and once we've done that we can then build on those basic values to construct more complex critiques. This gives us a kind of judgemental rationality about critique without moral certainty, and for that to work of course we have to have the thing that I've alluded to but haven't explained yet, which is a way of reasoning about basic values themselves.

This is where I want to turn to the work of Habermas, which both Chris Winship and Fred Vandenberghe have referred to before me. I suggest that one basis for establishing claims about basic values is to develop and build on what Habermas called the discourse principle. The discourse principle, according to Habermas, is the view that "just those action norms are valid to which all possibly affected persons could agree as participants in rational discourses" (Habermas, 1996, p. 107). I want to widen the scope of Habermas's point a touch. Rather than just action norms I think we can talk about ethical principles and normative claims in general: Just those ethical principles are valid to which all possibly affected persons could agree in this context. But what is a rational discourse in the context of ethical debate? Habermas argues that to be rational a discourse should be open, truthful and undistorted by differences in power. There are other elements but these are the key points, and these aren't just arbitrary considerations. For Habermas, the point is that if these conditions are not present then we cannot achieve genuine agreement. People can hardly be said to genuinely agree to something, if that agreement was procured by misleading them or if it was extorted from them under the influence of power. So it's intrinsic to the concept of genuine agreement that these conditions should hold.

Now I think this is an extremely attractive idea, but it's also an extraordinarily demanding standard to set for an ethical claim because it is extremely doubtful whether it could ever be fully met, at least when we are discussing issues of wide social relevance. Involving all possibly affected persons in an ethical discussion of such issues is rather challenging, but also the idea that we could ever be in a situation which was untouched by differences in power is highly problematic. Despite that, though, I think that we can make productive use of Habermas's principle by thinking of it, not as a condition 
that must be met, but rather as a kind of regulative ideal or standard. Applying this standard, we can say that a value is rational to the extent that it would be accepted in these kinds of circumstances: to the extent that we have grounds for believing it would be accepted in discussions that approximate to this ideal.

To move on to the last step of the argument, let me suggest that there are values that have already been arrived at through a reasonable approximation to that sort of process. In particular, consider the fundamental claim that we should value all humans, a claim which is relied on implicitly in a vast range of ethical discourses. There's one particular place where we might argue that this value has been arrived at through a process that conforms, as far as this might conceivably be viable at the global scale, to Habermas's discourse principle. That's in the United Nations Declaration of Human Rights. The declaration is far from a perfect expression of this principle, notably because of its neglect of LGBT rights. And yet, to quite a substantial extent it's a kind of formalisation of this principle that we should value all humans, which has been arrived at through a long discursive process - not just the formal negotiations about what should go in to the UN declaration, but also the whole political process that preceded that. That process includes the establishment of the United Nations as well as the making of the declaration, and both represent at least in part the outcome of a process in which anti-colonial movements in particular, anti-racist movements and women's movements were involved in a process of challenging existing social arrangements and values. In debates like these where values have been established with the active involvement of those people who are most marginalised, who are most powerless but nevertheless have been able to have a voice in the process then we come closest to meeting Habermas's discourse principle. Chris Winship has also given us another excellent example in his discussion of the way in which the case against slavery was built by abolitionists and former slaves in Haiti.

Now, if we can accept that, and I realise that this is quite a big, complicated, ambitious argument already, then we could build on this principle that we should value all humans to make further ethical claims and there are a couple of nice examples in the literature. Alison Assiter and Jeff Noone argue that if we combine this idea that we should value all humans with the recognition of the fact that humans have certain basic needs, then we can make the ethical argument that we have a duty to meet those basic human needs (Assiter \& Noonan, 2007). A similar argument can be found in the work of Sen and Nussbaum, who in the capabilities approach argue that if we value all humans and recognise that people need certain capabilities in order to function and flourish, then we have an obligation to ensure that those capabilities are available to them (Gasper, 2004, Chapter 7). Nussbaum's version of that capabilities list was itself developed through a long series of conversations with women's groups, 
in particular representing relatively marginalised women in the developing world, thus once again reflecting the spirit of Habermas's discourse principle (Nussbaum, 2000).

So, in conclusion, I argue that critical realists should discard moral realism. Instead we should think differently about the ontology of values, recognising that they are historically contingent social and human products. This need not, however, leave us in the grip of relativist ethical nihilism. We can still reason about values using the sorts of arguments I have developed here. The consequence is that we can have a judgementally rational basis for critique, we can provide compelling arguments for the critique of moral positions that neglect the interests and the views of the marginalised, but we must still recognise that the basis for critique is always and necessarily provisional. We can make strong critical arguments but we must always be aware that there are inevitably groups that have not yet made their voices heard, such as the LGBT community in the case of the UN Declaration of Human Rights. Hence this is an approach to values which demands that we maintain a degree of ethical humility and openness to the possibility that we may need to change our position as we learn more from those who have not yet been heard.

\section{References}

Assiter, A., \& Noonan, J. (2007). Human needs: a realist perspective. Journal of Critical Realism, 6(2), 173-198.

Bhaskar, R. (1986). Scientific realism and human emancipation. London: Verso.

Bhaskar, R. (1993). Dialectic: the pulse of freedom. London: Verso.

Bhaskar, R. (2002). Reflections on meta-reality. New Delhi: Sage.

Elder-Vass, D. (2010a). Realist critique without ethical naturalism or moral realism. Journal of Critical Realism, 9(1), 33-58.

Elder-Vass, D. (2010b). The Causal Power of Social Structures. Cambridge: Cambridge UP.

Gasper, D. (2004). The Ethics of Development. Edinburgh: Edinburgh UP.

Habermas, J. (1996). Between Facts and Norms. Cambridge: Polity.

Nussbaum, M. C. (2000). Women and Human Development: The Capabilities Approach. Cambridge: Cambridge UP. 